\section{Kombinasi Geotekstil dan Beronjong untuk Penanganan Kelongsoran \\ Lereng}

\section{Erwin Ananda Lubis ${ }^{1}$ Yulian Firmana Arifin ${ }^{2}$ \\ ${ }^{1}$ Konsultan Perencana dan Pengawas di Kabupaten Berau Kalimantan Timur \\ ${ }^{2}$ Program Studi Pendidikan Profesi Insinyur, Universitas Lambung Mangkurat}

erwin7477@yahoo.co.id
Penggunaan geotekstil dan beronjong sudah sangat umum digunakan pada perbaikan lereng terutama digunakan secara terpisah. Artikel ini fokus pada penggunaan kedua material perkuatan tersebut secara bersama-sama dimana keduanya berperan dalam peningkatan faktor keamanan lereng yang diperkuat. Lereng yang dibahas pada artikel ini adalah salah satu longsoran yang terjadi di daerah Berau Kalimantan Utara. Langkah-langkah perancangan yang diambil antara lain perhitungan tekanan tanah aktif, perhitungan tegangan izin tarik geotekstil, perhitungan jarak vertical geotekstil, perhitungan panjang geotekstil, perhitungan panjang lipatan, dan perhitungan stabilitas eksternal lereng. Langkah terakhir adalah kontrol stabilitas keseluruhan lereng baik dengan geotekstil maupun geotekstil dan beronjong. Hasil perhitungan memperlihatkan bahwa penambahan beronjong tidak hanya memberikan perlindungan kepada geotekstil dari sinar ultraviolet dan aliran air tapi juga meningkatkan faktor keamanan lereng. Analisa stabilitas lereng sangat penting untuk menentukan apakah beronjong berperan sebagai beban atau memberikan perlawanan.

Kata kunci: longsor, geotekstil, beronjong, stabilitas lereng

Diajukan: 31 Mei 2020

Direvisi: 15 Juni 2020

Diterima: 16 Juni 2020

Dipublikasikan online: 17 Juni 2020

\section{Pendahuluan}

Beronjong atau yang biasa disebut gabion dan geotekstil telah banyak digunakan sebagai perkuatan lereng. Umumnya penggunaannya secara terpisah masing-masing komponen. Akan tetapi dapat juga digunakan secara bersama-sama khususnya untuk lereng yang curam dan tingkat erosi tinggi. Beberapa keuntungan penggunaan gabion antara lain fleksibel, permeabilitas tinggi, ekonomis, ramah lingkungan, dan estetika (Toprak dkk, 2016). Ramli dkk (2013) melaporkan bahwa beronjong sangat cocok untuk daerah dengan kondisi orientasi pier jembatan yang buruk terhadap aliran air, arus aliran yang dibatasi, parikel berbutir halus rentan bergerak dengan kecepatan yang sangat kecil, dan peningkatan aliran air yang tidak dapat diprediksi, misalnya selama musim hujan. Disamping itu, Utmani dkk (2019) menambahkan bahwa beronjong mudah diperbaiki, cocok untuk beberapa jenis tanah, mudah dalam pelaksanaanya dan tidak terganggu dengan hujan lebat sekalipun, dan dapat berfunsi sebagai penyerap getaran khususnya disekitar rel kereta api. Dilihat dari banyaknya keuntungan tersebut, gabion banyak sekali digunakan sampai sekarang.

Toprak dkk (2016) menyatakan bahwa sebelum menggunakan gabion, jenis dan fungsinya harus diketahui dengan baik. Ada beberapa tipe gabion diantaranya gabion baskets, gabion mattresses, gabion sacks and gabion wire mesh yang masing-masing memiliki keunggulan dan kekurangan sehingga harus cocok dalam pemilihannya. Bagaimanapun, tipe yang paling banyak digunakan khususnya untuk perkuatan adalah jenis basket atau keranjang.

Artikel ini fokus pada penggunaan secara bersama antara geotekstil dengan beronjong yang digunakan sebagai perbaikan lereng yang mengalami longsor. Metode perancangan, analisis stabilitas perkuatan, dan stabilitas lereng dijelaskan dengan tahapan-tahapan yang jelas agar mudah dipahami oleh para insinyur yang tertarik untuk melakukan kegiatan yang serupa.

\section{Kondisi Lereng yang Longsor}

Gambar 1(a) dan 1(b) memperlihatkan foto-foto longsor yang terjadi di Kabupaten Berau, Kalimantan Timur. Longsor terjadi di bahu jalan dan mulai bergerak ke arah badan jalan. Lapisan tanah pada lereng yang terjadi longsor diuji dengan pendekatan menggunakan data sondir seperti terlihat pada Gambar 2. Berdasarkan data sondir, tanah didaerah yang longsor adalah tanah kaku sampai dengan sangat kaku dengan $q_{c} 20-40 \mathrm{~kg} / \mathrm{cm}^{2}$ sampai kedalaman 4 meter. Selebihnya tanahnya relatif keras. Jika dianalisis dari data tanah tersebut dan lalulintas yang relatif tidak terlalu padat, penyebab terjadinya longsor mungkin disebabkan oleh faktor eksternal yaitu air.

Cara mensitasi artikel ini:

Lubis E. A., Arifin, Y.F. (2020) Penggunaan geotekstil dan beronjong untuk penanganan kelongsoran lereng. Buletin Profesi Insinyur 3(1) 039-044 


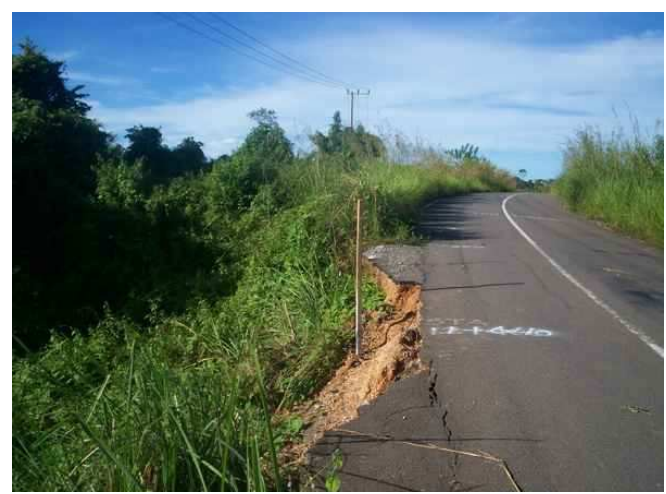

(a)

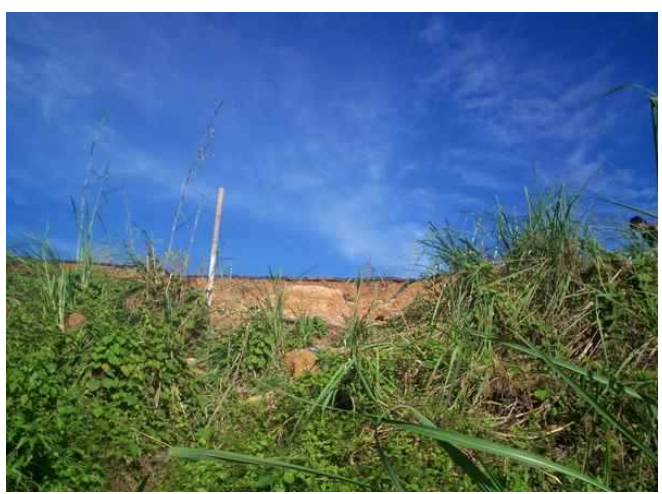

(b)

Gambar 1 Foto-foto visual longsor (a) sejajar arah badan jalan, dan (b) dari dasar longsoran.

Profil lereng yang longsor terlihat pada Gambar 3. Tipe keruntuhan yang terjadi adalah keruntuhan lereng dengan jarak kurang lebih 5 meter dari permukaan jalan. Dengan bantuan software analisis stabilitas lereng, dapat diketahui garis keruntuhan yang persis seperti terjadi di lapangan dengan faktor keamanan 1.16 (kritis). Disamping diperlukan perbaikan, lereng juga membutuhkan perkuatan yang tidak hanya mampu menahan gaya-gaya internal dan eksternal, juga aman Ketika terjadi aliran air dipermukaan lereng.

\section{Perancangan Perkuatan Lereng}

Analisa perkuatan lereng dengan menggunakan geotektil mengikuti yang disarankan oleh Das (2011). Tipe geotekstil yang digunakan adalah geotekstil woven dengan kuat tarik $37 \mathrm{kN} / \mathrm{m}$. Berat volume tanah asli adalah $16,5 \mathrm{kN} / \mathrm{m}^{3}$, dengan sudut gesek dalam $25^{\circ}$. Tanah urug yang digunakan menggunakan data tanah yang sama karena material yang digunakan relatif sama.

\section{Langkah Pertama}

Langkah pertama yang dilakukan adalah perhitungan tekanan tanah aktif (Das, 2011). Dari data-data tadi didapatkan koefisien tekanan tanah aktif $\mathrm{K}_{\mathrm{a}}=0.41, \sigma_{\mathrm{a}}$ dan $\sigma_{v}$ masing-masing $25,6 \mathrm{kN} / \mathrm{m}^{2}$ dan $63 \mathrm{kN} / \mathrm{m}^{2}$. Beban lalu lintas yang bekerja adalah $15 \mathrm{kN} / \mathrm{m}^{2}$.

\section{Langkah Kedua}

Langkah kedua yang dilakukan adalah menghitung tegangan tarik izin geotekstil dengan menggunakan Persamaan 1.

$T_{a l l}=\frac{T_{u l t}}{R F_{i d} \times R F_{c r} \times R F_{c b d}}$

Dimana Tult adalah kekuatan tarik batas, $R F_{i d}$ faktor reduksi akibat kerusakan pemasangan, $R F_{c r}$ adalah faktor reduksi rangkak (creep), dan $R F_{c b d}$ faktor reduksi
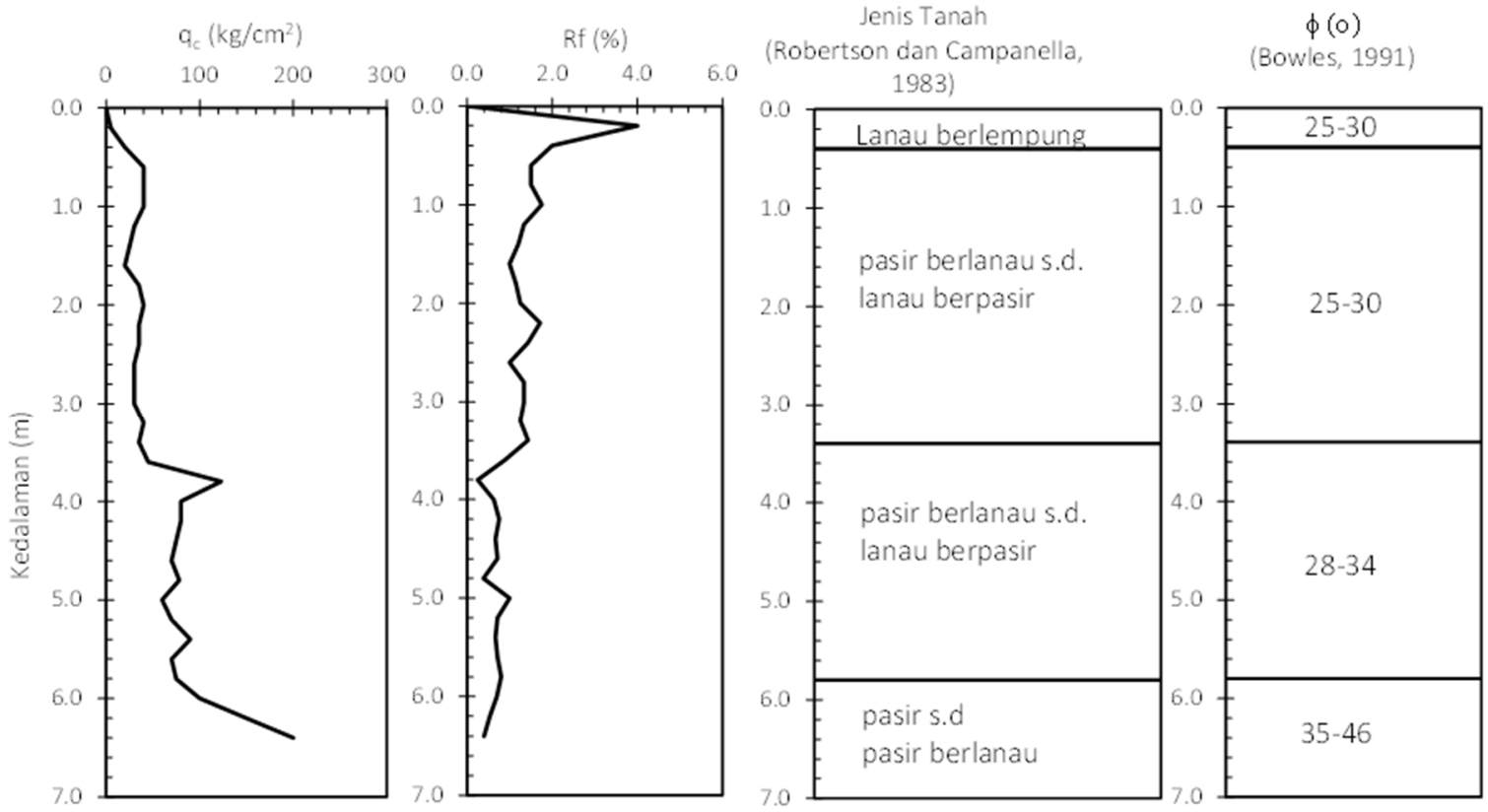

Gambar 2. Data sondir dan profil sublapisan tanah 


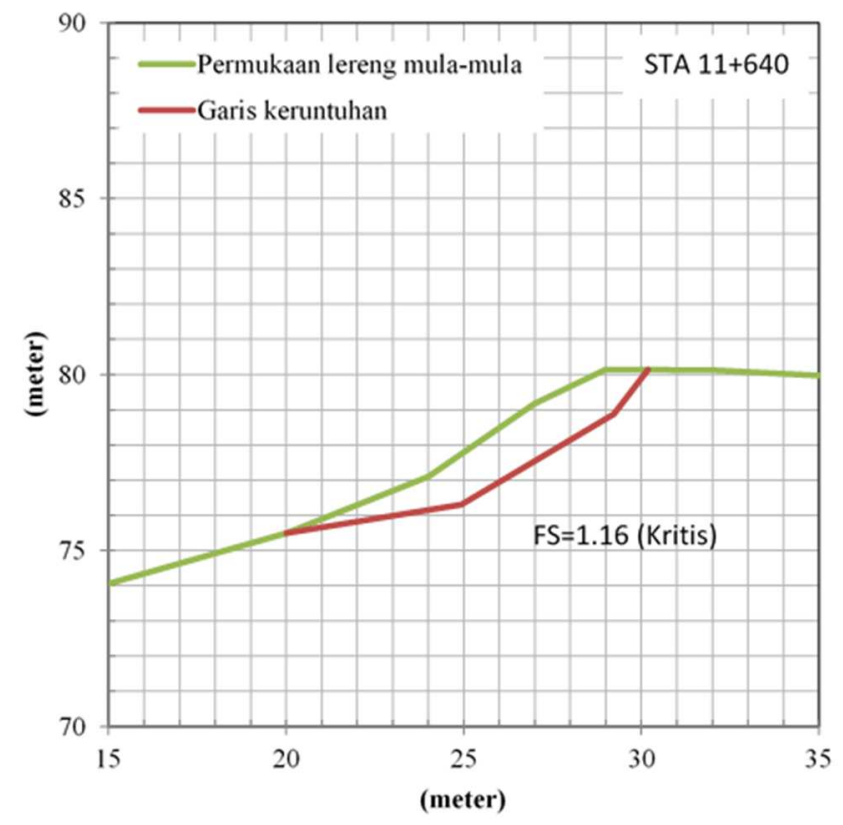

Gambar 3. Kondisi lereng dan garis keruntuhan (faktor keamanan 1,16)

kerusakan kimia dan biologi. Koerner (2005) menyarankan $R F_{i d} 1,1-2,0, R F_{c r}$ 2-4 dan $R F_{c b d}$ 1-1,5.

\section{Langkah Ketiga}

Langkah selanjutnya (ke tiga) adalah menghitung jarak vertikal geotekstil dengan menggunakan Persamaan 2. Faktor keamanan yang disarakan adalah 1,3-1,5 (Das, 2011)

$S_{v}=\frac{T_{a l l}}{\sigma^{\prime}{ }_{a} \times F S}$

Dari data-data yang ada, $S_{v}$ yang didapat dalah $0,7 \mathrm{~m}$ sehingga direncanakan jumlah lapisan 6 lapis dengan jarak 0,5 m untuk menyesuaikan dengan dimensi beronjong yang digunakan.

\section{Langkah Keempat}

Langkah yang keempat adalah perhitungan panjang geotekstil yang digunakan. Umumnya, panjang geotekstil dihitung dengan menjumlahkan panjang geotekstil di depan garis keruntuhan $\left(L_{r}\right)$ dan di belakang garis keruntuhan $\left(L_{e}\right)$. Dalam kasus ini, $I_{r}$ dihitung dengan mempertimbangkan jarak dari permukaan lereng sampai dengan garis keruntuhan. Sedangkan panjang geotekstil di belakang garis kerutuhan dihitung dengan menggunakan Persamaan 3.

$L_{e}=\frac{S_{v} \sigma_{a}^{\prime}\left[F S_{(P)}\right]}{2 \sigma_{\prime}{ }_{o} \tan \emptyset \prime_{F}}$

dimana $\mathrm{FS}_{(\mathrm{P})}$ 1,3-1,5 dan $\phi_{\mathrm{F}}^{\prime}$ yaitu sudut gesek permukaan geotekstil dan tanah $\approx 2 / 3 \phi^{\prime}$. Perhitungan $L_{e}$ dirangkum pada Tabel 1 . Dari tabel didapat, $L_{e}$ yang didapat adalah $0,1 \mathrm{~m}$ sehingga digunakan panjang minimum yaitu $1 \mathrm{~m}$. Kondisi penempatan geotekstil dengan panjang 1 meter di belakang garis keruntuhan terlihat pada Gambar 4.

Tabel 1. Perhitungan $L_{e}$

\begin{tabular}{ccccc}
\hline $\begin{array}{c}\mathrm{z} \\
(\mathrm{m})\end{array}$ & $\begin{array}{c}\sigma_{\mathrm{a}}^{\prime} \\
\mathrm{t} / \mathrm{m}^{2}\end{array}$ & $\begin{array}{c}\sigma_{\mathrm{v}}^{\prime} \\
\mathrm{t} / \mathrm{m}^{2}\end{array}$ & $\begin{array}{c}\mathrm{S}_{\mathrm{v}} \\
(\mathrm{m})\end{array}$ & $\begin{array}{c}L_{e} \\
(\mathrm{~m})\end{array}$ \\
\hline 0.5 & 0.9 & 2.3 & 0.5 & 0.1 \\
1 & 1.3 & 3.1 & 0.5 & 0.1 \\
1.5 & 1.6 & 3.9 & 0.5 & 0.1 \\
2 & 1.9 & 4.7 & 0.5 & 0.1 \\
2.5 & 2.2 & 5.5 & 0.5 & 0.1 \\
3 & 2.6 & 6.3 & 0.5 & 0.1 \\
\hline
\end{tabular}

\section{Langkah Kelima}

Langkah kelima adalah menghitung panjang lipatan dengan menggunakan Persamaan 4. Panjang minimum lipatan adalah $1 \mathrm{~m}$. Perhitungan besarnya Li dirangkum pada Tabel 2. Dari tabel didapat panjang Li 0,1 dan 0,2 meter. Sehingga diambil panjang minimum yaitu $1 \mathrm{~m}$.

$L_{l}=\frac{S_{v} \sigma{ }^{\prime} F S_{(P)}}{4 \sigma{ }^{\prime}{ }_{o} \tan \emptyset \prime_{F}}$

Tabel 2. Perhitungan $L_{i}$

\begin{tabular}{ccccc}
\hline $\begin{array}{c}z \\
(\mathrm{~m})\end{array}$ & $\begin{array}{c}\sigma_{a}^{\prime} \\
\mathrm{t} / \mathrm{m}^{2}\end{array}$ & $\begin{array}{c}\sigma_{v}^{\prime} \\
\mathrm{t} / \mathrm{m}^{2}\end{array}$ & $\begin{array}{c}S_{v} \\
(\mathrm{~m})\end{array}$ & $\begin{array}{c}L_{i} \\
(\mathrm{~m})\end{array}$ \\
\hline 0.5 & 1.1 & 2.3 & 0.5 & 0.1 \\
1 & 2.1 & 3.1 & 0.5 & 0.1 \\
1.5 & 3.2 & 3.9 & 0.5 & 0.1 \\
2 & 4.3 & 4.7 & 0.5 & 0.2 \\
2.5 & 5.4 & 5.5 & 0.5 & 0.2 \\
3 & 6.4 & 6.3 & 0.5 & 0.2 \\
\hline
\end{tabular}

Langkah ke enam adalah perhitungan stabilitas eksternal yang meliputi stabilitas terhadap guling, geser, dan daya dukung. Untuk menghitung stabilitas 


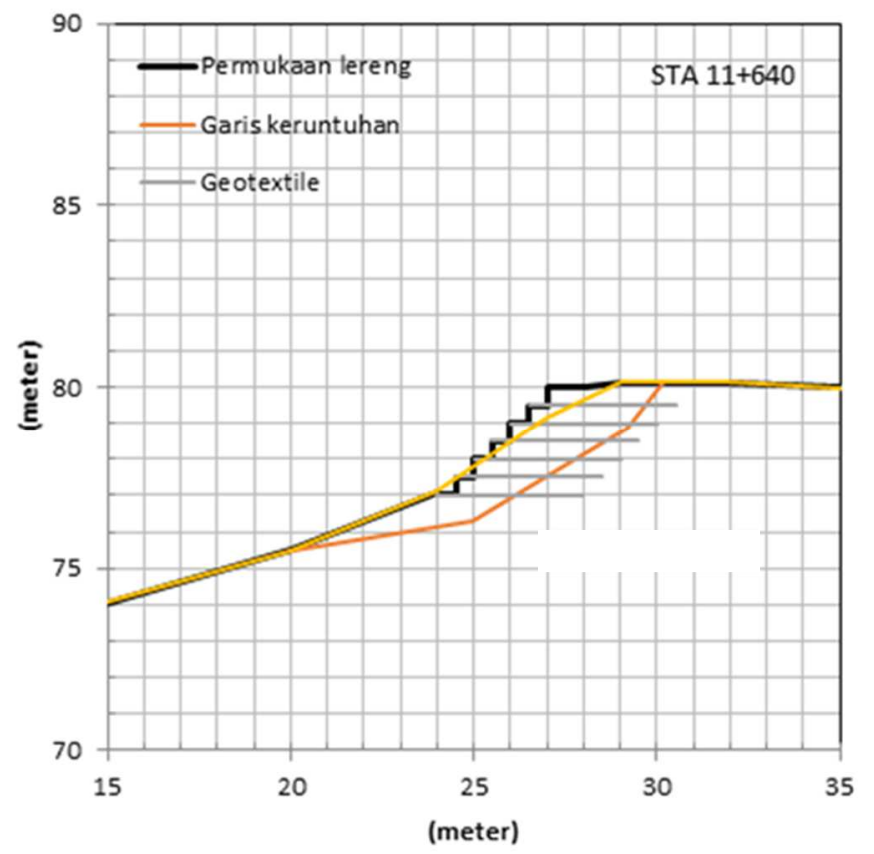

Gambar 4. Penentuan panjang geotekstil menggunakan garis keruntuhan awal

guling, maka terlebih dahulu menghitung momen yang menahan (MR) dan yang mendorong (Mo). Tabel 3 adalah ringkasan perhitugan momen yang menahan (MR) dan momen pendorong (Mo), dimana hasil perhitungannya, Mo=144 kN.m dan MR=849 kN.m. Faktor keamanan didapat 5,9. Syarat faktor keamanan minimum guling adalah 2,0 (SNI 8460, 2017) yang diekstrak dari FHWA NHI 00043.

Tabel 3. Perhitungan $M_{R}$ dan $M_{0}$

\begin{tabular}{cccccc}
\hline Lap. & $\begin{array}{c}\mathrm{L} \\
(\mathrm{m})\end{array}$ & $\begin{array}{c}S_{V} \\
(\mathrm{~m})\end{array}$ & $\begin{array}{c}\mathrm{W} \\
(\text { ton })\end{array}$ & $\begin{array}{c}\text { jarak } \\
(\mathrm{m})\end{array}$ & $\begin{array}{c}\mathrm{M}_{\mathrm{R}} \\
(\text { t.m) }\end{array}$ \\
\hline 1 & 4 & 0.5 & 3.2 & 2 & 6.4 \\
2 & 4 & 0.5 & 3.2 & 2.5 & 8 \\
3 & 4 & 0.5 & 3.2 & 3 & 9.6 \\
4 & 4 & 0.5 & 3.2 & 3.5 & 11.2 \\
5 & 4 & 0.5 & 3.2 & 4 & 12.8 \\
6 & 4 & 0.5 & 3.2 & 4.5 & 14.4 \\
\hline Beban & & & & & \\
LL & & & 4.5 & 5 & 22.5 \\
\hline Total & & & 23.7 & & 84.9 \\
\hline
\end{tabular}

Untuk menghitung stabilitas terhadap geser, dilakukan dengan membandingkan gaya yang menahan geser dengan gaya yang mendorong masing-masing dihitung dengan Persamaan 5 dan 6 . Dari perhitungan didapat faktor keamanan terhadap geser 2,4. Faktor keamanan minimal untuk geser adalah 1,5 (SNI 8460, 2017)

$P_{R}=w_{\text {total }} \tan (2 / 3 \varnothing)$

$P_{a}=0,5 \gamma H^{2} K_{a}$

Stabilitas daya dukung dihitung dengan menggunakan persamaan daya dukung pondasi dangkal (Persamaan 7). $N_{c}, N_{q}$, dan $N_{\gamma}$ adalah faktor daya dukung yang nilainya tergantung sudut gesek dalam tanah di bawah konstruksi. Dari hasil perhitungan didapat $\mathrm{Q}_{u}$ $347,8 \mathrm{kN} / \mathrm{m}^{2}$ dan $\sigma_{\mathrm{v}} 63 \mathrm{kN} / \mathrm{m}^{2}$. Faktor keamanan yang didapat untuk daya dukung adalah 5,5. Faktor keamanan minimal untuk stabilitas daya dukung pondasi adalah 2,5 (SNI 8460, 2017).

$Q_{u}=c N_{c}+q N_{q}+1 / 2 \gamma d N_{\gamma}$

Langkah selanjutnya yang paling penting adalah menganalisis stabilitas keseluruhan lereng. Gambar 5 memperlihatkan garis keruntuhan lereng setelah digunakan geotekstil. Faktor keamanan yang didapat adalah 1,46. Berdasarkan SNI 8460 tahun 2017 faktor keamanan 1,25 sudah cukup untuk lereng seragam dengan kondisi tanah yang pasti. Dan Faktor keamanan 1,3 untuk lereng dengan perkuatan geotekstil. Akan tetapi, dilihat dari proses terjadinya keruntuhan lereng lebih disebabkan oleh adanya aliran air maka faktor keamanan 1,5-2,0 biasa digunakan.

Untuk kondisi lereng dimana titik keruntuhan berada di atas lereng, maka menambahkan beronjong dapat menjadi upaya untuk meningkatkan faktor keamanan lereng. Arifin (2018) juga menekankan pentingnya memperhitungkan kemiringan lereng dalam analisa stabilitas lereng dengan perkuatan. Gambar 6 memperlihatkan hasil analisa stabilitas lereng setelah dipasang beronjong, dimana beronjong dianggap sebagai beban yang dalam perhitungannya justru meningkatkan momen penahan. Faktor keamanan yang didapat adalah 1.5.

Gambar 7 memperlihatkan foto visual lereng setelah 1 tahun selesai dikerjakan. Lereng terlihat sangat stabil dan lebih kokoh dengan kombinasi geotekstil dan beronjong tersebut.

Beberapa hal yang harus diperhatikan dalam pelaksanaan adalah kemungkinan ditemukannya aliran air sehingga subdrain yang baik dengan menggunakan 


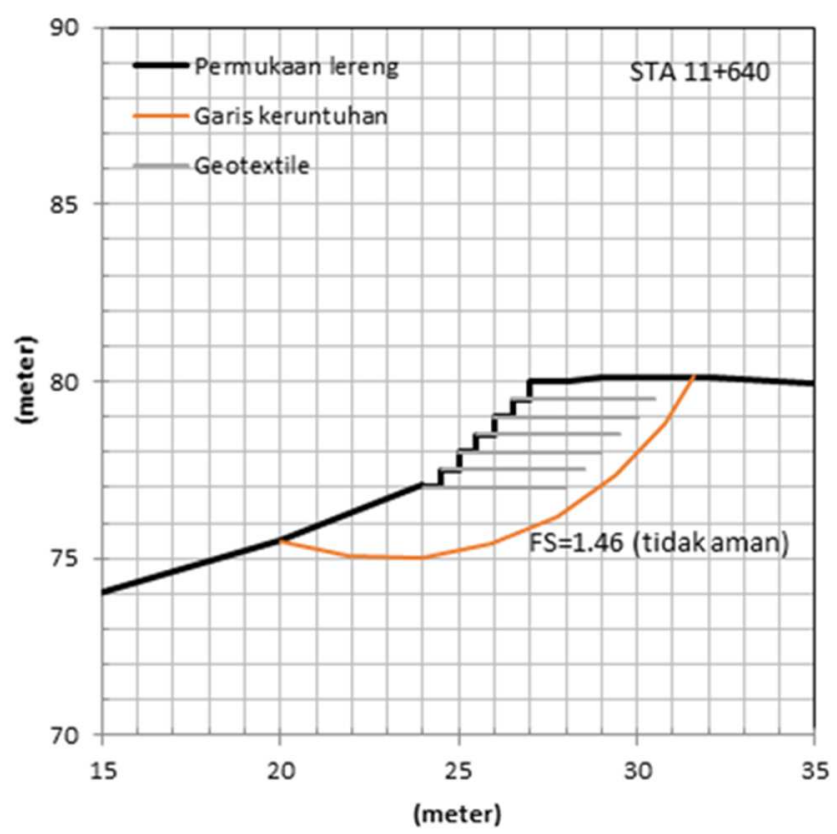

Gambar 5 Analisis stabilitas lereng secara keseluruhan setelah digunakan geotekstil

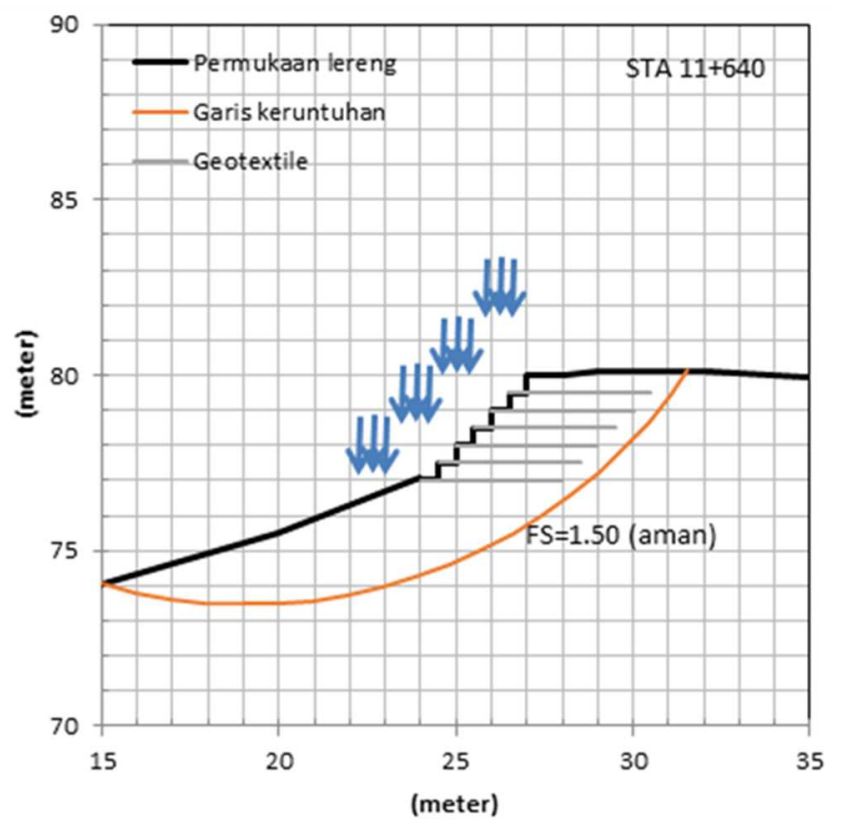

Gambar 6 Kontrol stabilitas keseluruhan lereng dengan penambahan beronjong

geotekstil nonwoven dan kerikil harus benar-benar dilaksanakan untuk menghindari air masuk ke dalam lereng. Hal lain yang perlu diperhatikan adalah bahwa timbunan dipadatkan pada kadar air $\pm 2 \%$ kadar air optimum (SNI 8640, 2017).

\section{Kesimpulan}

Perancangan perbaikan lereng dengan geotekstil dan beronjong telah dipaparkan dengan tahapan-tahapan antara lain:

1. Perhitungan tekanan tanah aktif lereng yang diawali dengan menghitung koefisien tekanan tanah aktif.
2. Perhitungan tegangan tarik izin geotekstil. Mempertimbangkan kerusakan pemasangan, rangkak, dan faktor reduksi karena proses kimia dan biologi.

3. Perhitungan jarak vertical geotekstil

4. Perhitungan panjang geotekstil. Untuk Kasus perancangan perbaikan lereng akibat longsoran, panjang geotekstil dihitung di belakang garis keruntuhan dengan panjang minimal 1 meter.

5. Perhitungan panjang lipatan dengan mempertimbangkan panjang minimal 1 meter. 

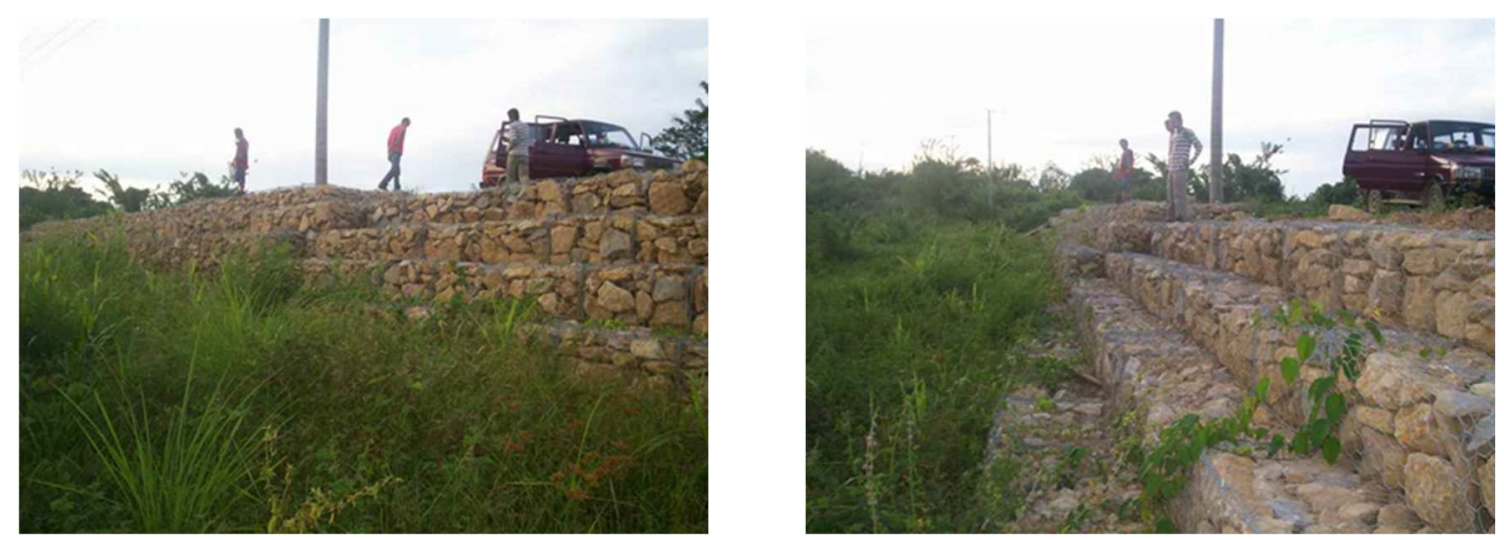

Gambar 7 Foto visual lereng setelah 1 tahun

6. Perhitungan stabilitas eksternal yang meliputi stabilitas guling, geser, dan daya dukung. Langkah terakhir yang merupakan analisis paling penting adalah control stabilitas secara keseluruhan. Pada langkah inilah, beronjong dapat digunakan tidak hanya sebagai pelindung geotekstil dari sinar matahari dan proses aliran air permukaan, akan tetapi juga dapat digunakan untuk meningkatkan faktor keamanan.

\section{Referensi}

Arifin, Y.F (2018) Pengaruh Panjang dan. Kemiringan Lereng terhadap. Stabilitas Keseluruhan Sheet. Pile di Tanah Lunak, Buletin Profesi Insinyur 1(1), 1-4.

Bowles, J. E. (1991). Sifat-sifat Fisis dan Geoteknis Tanah (Mekanika Tanah). Erlangga: Jakarta.

Das, B.M., (2011) Principle of Foundation Engineerings (Seventh Edition), Cengage Learning, USA.
Koerner, R. B. (2005) Design with Geosynthetics, 5th. ed., Prentice Hall, Englewood Cliffs, NJ.

FHWA-NHI-00-043 (2001) Mechanically stabilized earth walls and reinforced soil slopes design \& construction guidelines, Federal Highway Administration, U.S. Department of Transportation

Ramli, M., Karasu, T. J. r., dan Dawood, E. T. (2013). The stability of gabion walls for earth retaining structures. Alexandria Engineering Journal, 52(4), 705-710. doi:10.1016/j.aej.2013.07.005

Robertson P.K. dan Campanella, R.G (1983) Interpretation of cone penetration tests. Part I: Sand, Canadian Geotechnical Journal 20, 718-733

SNI 8460 (2017) Persyaratan perancangan geoteknik, Badan Standarisasi Nasional Indonesia.

Toprak, B., Sevim, O., Kalkan, I (2016) Gabion walls and their use, International Journal of Advances in Mechanical and Civil Engineering 3(4) 56-58.

Utmani N, Ahmad S, Islam RU, Abbas M (2019) Gabion wall used in road construction and flood protection embankment. J Civil Eng Environ Sci 5(1): 001-004.DOI http://doi.org/10.17352/2455-488X.000031 